\title{
MAKNA RUWAYBIDAH DAN RUMUSAN ETIKA KOMUNIKÁSI DI ERA DIGITAL
}

\author{
Moh. Nailul Muna \\ Universitas Islam Negeri Sunan Kalijaga Yogyakarta \\ m.nailulmuna7@gmail.com
}

\begin{abstract}
This study aims to discuss the ethics of public communication in a digital age, based on the hadith perspective. It is based on the poor ethics of communication in society, which leads to the emerge of SARA, hoaxes, and politicization of religion. The article addresses prophetic traditions concerning ruwaybidab that could provide values on the norms of communication. Based on the lexical meaning, the word ruwaybidab means people who are weak towards noble matters. Muhammad's description through the editorial "fools who meddled in community affairs" has a close relation to the cause of social inequality at that time. Through a socio-historical approach, it argues that anyone who does not have capabilities in a particular field and tries to impose his or her incapacity, they could belong to the ruwaybidab category. Further, this study attempts to formulate key important principles of today's digital age communication based on the hadith.
\end{abstract}

Keywords: Hadith, Communication ethics, Ruwaybidah.

Abstrak: Kajian ini bertujuan untuk membahas etika komunikasi publik di era digital dalam perspektif hadis. Hal ini dilatari oleh buruknya etika komunikasi di masyarakat yang menyebabkan munculnya SARA, hoax, dan politisasi agama. Artikel ini mengkaji hadis tentang ruwaybidah yang memberikan nilai tentang norma-norma dalam berkomunikasi, seperti: menyerukan pentingnya kompetensi seseorang dalam proses berkomunikasi. Dalam arti leksikal, kata ruwaybidah bermakna orangorang yang lemah terhadap perkara-perkara yang luhur. Deskripsi nabi melalui redaksi "orang-orang bodoh yang turut campur dalam urusan masyarakat", berkaitan dengan penyebab ketimpangan sosial di masa tersebut. Melalui pendekatan sosio-historis, ditemukan bahwa setiap orang yang tidak mempunyai kapabilitas dalam bidang tertentu dan mencoba untuk memaksakan ketidak-mampuannnya, termasuk dalam kategori Ruwaybidah. Lebih jauh, artikel ini mencoba untuk merumuskan etika komunikasi publik di era digital dalam perspektif hadis.

Kata Kunci: Hadis, Etika Komunikasi, Ruwaybidah. 


\section{Pendahuluan}

Indonesia adalah negara yang menjunjung tinggi prinsip kemerdekaan pendapat, dan berekspresi. Sebagaimana yang tertuang dalam UUD 1945 Pasal 28F "setiap orang berhak untuk berkomunikasi dan memperoleh informasi untuk mengembangkan pribadi dan lingkungan sosialnya, serta berhak untuk mencari, memperoleh, memiliki, menyimpan, mengolah, dan menyampaikan informasi dengan menggunakan segala jenis saluran yang tersedia." Kebebasan tersebut, bukan hanya memberikan dampak positif, namun juga dampak negatif berupa banyaknya kasus boax di Indonesia.

Hoax saat ini telah menjadi ancaman nyata. Masyarakat modern, hampir semuanya terkena paparan media yang sebagian besar, membawa kabar bernuansa kebohongan dalam setiap sudut dunia maya. ${ }^{2}$ Beberapa kasus, seperti anarkisme di Papua, telah cukup menjadi bukti bagaimana hoax dapat menyebabkan chaos di setiap lapisan masyarakat, yang nantinya berujung pada disintegrasi isosial dan perpecahan antar anak bangsa.

Akselerasi penyebaran boax didorong oleh kecanggihan teknologi di era digital. Dengan sirkulasi informasi melalui cyberspace, boax menjadi tak terkendali, sekaligus dapat menyebar dan menyasar tanpa batasan waktu dan tempat. Indonesia yang memiliki pengguna internet sebanyak 130 juta jiwa sampai bulan Oktober 2016, atau naik 41,9 juta orang dibandingkan dengan 2014 yang baru 88,1 juta orang, tentu menjadi ladang subur bagi berkembangnya hoax. Terlebih, dari 88,1 juta pengguna tersebut, 79 juta adalah pengguna aktif media sosial, dengan 66 juta di antaranya menggunakan telepon pintar (smartphone). ${ }^{3}$

Meski demikian, boax bukanlah persoalan teknologi, apalagi persoalan yang hanya menyangkut teori komunikasi. Seperti teori tentang kultivasi, uses and gratification, determinisme teknologi, spiral of silence, dan teori agenda setting. ${ }^{4}$ Hoax secara ontologis merupakan

${ }^{1}$ Heri Budianto dan Farid Hamdi, Ilmu Komunikasi: Sekarang dan Tantangan Masa Depan (Jakarta: Kencana, 2013), 332.

${ }^{2}$ Errika Dwi Setya Watie, "Communication and Social Media", dalam Jurnal The Messenger, Vol. 3, No. 1 (2011), 69.

3 Haris Sumadiria, Hukum dan Etika Media Massa (Bandung: Rosdakarya offset, 2016), 205.

${ }^{4}$ Beberapa penjelasan lainnya mengarah kepada teknologi komunikasi, dengan dikategorikan menjadi dua: Pertama, Media Baru. Kedua, Media Tradisional. Lihat, 
problem tentang etika manusia ketika berupaya menyampaikan dan menerima informasi. Oleh karena itu, eksplorasi atas kasus hoax seyogyanya terfokus kepada formulasi norma-norma manusia ketika berada dalam proses komunikasi.

Dalam kajian teks keislaman, terdapat hadis tentang ruwaybidah yang dapat dijadikan landasan dalam menelaah hal tersebut. Secara bahasa, kata ruwaybidah merupakan bentuk tasghir dari kata rabidah yang berarti orang yang lemah terhadap perkara-perkara yang luhur. ${ }^{5}$ Sedangkan menurut riwayat Anas, kata tersebut bermakna orang fasik yang berbicara dalam urusan umat. ${ }^{6}$ Namun di era modern, makna ruwaybidah dapat diperluas melebihi arti literalnya, yang dalam kajian ini akan diinterpretasikan melalui perspektif kritik sejarah dan kritik bahasa.

Hadis ruwaybidah merupakan hadis prediktif yang memberikan informasi akan munculnya banyak kerusakan moral, termasuk banyaknya tipu-daya manusia. Dalam hadis tersebut digambarkan bahwa orang pendusta akan dibenarkan, sedangkan orang yang benar akan didustakan. Hal ini menunjukkan ketimpangan sosial yang sebenarnya tidak jauh beda dengan fenomena-fenomena yang muncul akhir-akhir ini. Hal tersebut merupakan sebuah indikator bahwa ruwaybidah di era modern bisa berupa banyak bentuk, dan hal tersebut disebabkan majunya teknologi di zaman modern. Oleh karena itu, menelusuri makna ruwaybidah secara komprehensif menjadi penting untuk dilakukan.

\section{Deskripsi Hadis}

Hadis utama yang menjadi objek kajian dalam artikel ini, merupakan hadis yang diriwayatkan oleh Ibn Majah dalam Sunan Ibn Majjab :

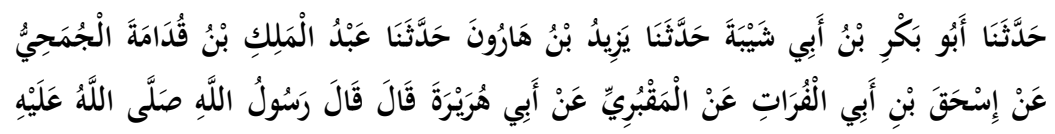

Novi Kurnia, "Perkembangan Teknologi Komunikasi dan Media Baru: Implikasi terhadap Teori Komunikasi”, Jurnal Mediator, Vol. 6, No. 2 (2005), 291-296.

5 A.W. Munawwir, Kamus Al-Munawwir Arab-Indonesia Terlengkap (Surabaya: Pustaka Progressif, 1997), 465.

${ }^{6}$ Ismā̄il b. 'Umar b. Kathï, Al-Bidāyah wa al-Nihāyah (Riyad: Dār al-Wațan, 2002), 135.

7 Abū 'Abd Allāh Muhammad b. Yazìd b. Mājah al-Qazwayni, Sunan Ibn Mājah, Hadis no. 4036 (Riyad: Dār al-Khaḍrā', 2015), 623. 


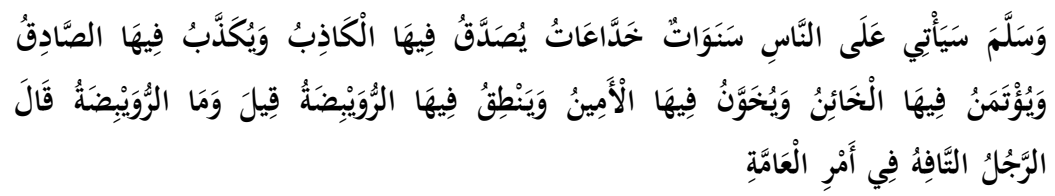

"Abū Bakr b.Abi Shaybah menuturkan kepada kami. Dia berkata; Yazìd b. Hārūn menuturkan kepada kami. Dia berkata; 'Abd alMālik b. Qudāmah al-Jumāḥ̄i menuturkan kepada kami dari Ishạă b.Abìi al-Farrāt dari al-Maqburi dari Abū Hurayrah, dia berkata; Rasulullah bersabda: "Akan datang kepada manusia tahun-tahun yang penuh dengan penipuan. Ketika itu pendusta dibenarkan sedangkan orang yang jujur malah didustakan, pengkhianat dipercaya sedangkan orang yang amanah justru dianggap sebagai pengkhianat. Pada saat itu ruwaybidah berbicara." Ada yang bertanya, "Apa yang dimaksud ruwaybidab?". Dia menjawab, "Orang bodoh yang turut campur dalam urusan masyarakat luas."

Dalam penelitian sebuah hadis, penelusuran atas keotentikan hadis menjadi hal yang harus didahulukan. Merujuk hadis yang diriwayatkan oleh Abū Hurayrah, dalam Sunan Ibn Majah. Setidaknya, terdapat 6 perawi yang meriwayatkan sampai ke mukharrij yang disini bernama Abū 'Abd Allāh b. Muḥammad b. Yazīd b. Majah alQazwini. Keenam perawi tersebut secara beruntun ialah: Abū Hurayrah, al-Maqburi, Isḥāq b. Ab̄i Furāt, 'Abd al-Mālik b. Qudāmah al-Jumahịi, Yazìd b. Hārūn, dan Abū Bakr b. Abì Shaybah. Ketujuh perawi tersebut, termasuk Ibn Majah akan di deskripsikan secara singkat untuk melihat kualitas hadis berdasarkan teori al-jarb wa alta'dìl, baik meliputi naqd al-sanad (kritik sanad) maupun naqd al-matn (kritik matan).

a. Naqd al-Sanad

Pertama, Abū Hurayrah. ${ }^{8}$ Dalam Tahdhīb al-Kamāl dijelaskan, bahwa dia bertemu secara langsung dengan Rasulullah. ${ }^{9}$ Secara umum, mayoritas ulama meyakininya sebagai orang yang thiqqah (dapat dipercaya). ${ }^{10}$ Meninjau sebauh teorem bahwa setiap sahabat bernilai 'udul (adil),' maka bisa dipastikan, bahwa Abū Hurayrah termasuk

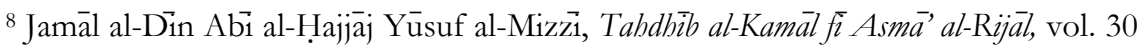
(Beirut: Mu'assasat al-Risālah, 1983), 154.

'Ibid., 159.

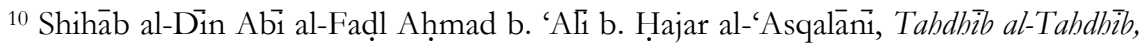
vol.3 (Beirut: Mu’assasat al-Risālah, 1995), 132.

${ }^{11}$ Muhammad 'Ajjā b. Khațīb, Ușül al-Hadith (Beirut: Dār al-Fikr, 2011), 256.
} 
kategori perawi yang dapat dipegangi periwayatannya, sekaligus hal ini dikuatkan melalui ta'dil (penilaian baik) oleh para ulama-ulama yang lain.

Kedua, al-Maqburi. ${ }^{12}$ Adapun sanadnya terhitung bersambung, baik kepada Abū Hurayrah maupun kepada Isḥāq b. Abī Furāt alMadini. ${ }^{13}$ Sedangkan penilaian para ulama kepada dia yakni: (1). AlJurjāni: orang yang jujur. (2). Abū Ḥātim al-Rāzì sadūq (baik). (3). Abū Zur'ah: thiqqah (dapat dipercaya). (4). Ahmad al-Nasāis: thiqqah. Berdasarkan pada ta'dil oleh para ulama tersebut, menunjukkan bahwa al-Maqburi merupakan perawi yang dapat dipercaya, sedangkan riwayatnya terbukti tersambung dengan Abū Hurayrah.

Ketiga, Ishāa b. Abì al-Furāt. ${ }^{14}$ Sanadnya terbukti bersambung

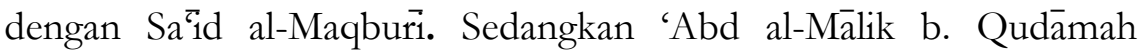
termasuk juga muridnya. ${ }^{15}$ Para ulama menilainya sebagai orang yang majbül (tidak diketahui). ${ }^{16}$ Keterangan tentang biografinya tidak banyak ditemukan, maka perawi ini dianggap majbu $\bar{l}$, atau dapat dikategorikan sebagai perawi yang dhaif. Meski demikian, ketersambungan sanad dengan perawi sebelumnya yakni Sa $\bar{i} d$ al-Maqburi, bisa dijadikan pertimbangan.

Keempat, 'Abd al-Mālik b. Qudāmah al-Jumaḥì. Dijelaskan bahwa dia merupakan perawi yang maqbül (diterima). ${ }^{17}$ Sedangakan mengenai ketersambungan sanad, dia terbukti bertemu dengan gurunya (Ishāa b. Abi Furāt) dan muridnya (Yazid b. Hārūn). ${ }^{18}$ Adapun penilaian para ulama terhadapnya adalah: (1) Abū Hātim: riwayat hadisnya lemah. (2) Abū Zur'ah: dia disebutkan dalam kitab al-Ḍu'afa', (menunjukkan bahwa ia termasuk perawi yang lemah). (3) Al-'Ijili: thiqqah (dipercaya). (4) Ibn 'Abd al-Barr: thiqqah. (5) Yahyā b. Ma⿳亠丷⿵冂: sălih (baik) dan thiqqah. ${ }^{19}$ Melalui penjelasan tersebut, dapat ditemukan bahwa 'Abd alMālik b. Qudāmah, bukan termasuk orang yang kuat hafalannya.

\footnotetext{
12 Abi 'Abd Allāh Muḥammad b. Aḥmad al-Dhahabi, Mīzān al-I'tidāl fĭ Naqd al-Rijāl, vol. 5 (Beirut: Dār al-Kutub al-'Ilmìyah, 1995), 78.

${ }^{13}$ Ibid.,80-92.

${ }^{14}$ Al-Mizzi, Tahdhīb al-Kamāl, vol. 17, 121.

${ }^{15}$ Ibid.,125-127

16 Ibid., 128.

17 Abi 'Abd Allāh Muḥammad b. Aḥmad al-Dhahabi, Siyār A läm al-Nubalā', vol. 14 (Beirut: Mu'assasat al-Risalah), 66.

18Ibid., 67-78.

${ }^{19}$ Al-Dhahabi, Mìzàn al-I'tidāl, vol. 7, 98.
} 
Sedangkan sanadnya masih tersambung dengan gurunya, yakni Isḥ̄à b. Abi Furāt.

Kelima, Yazid b. Hārūn. Dalam Tahdhìb al-Kamāl, dijelaskan bahwa sanadnya bersambung, baik dengan perawi sebelumnya maupun perawi setelahnya. ${ }^{20}$ Para ulama secara umum meyakini bahwa dia adalah orang yang thiqqah, seperti Ibn Hajar al-'Asqalāni, Abū Hạatim al-Rāzi, Aḥmad b. Hanbal yang menilainya sebagai ḩăfiz mutqin alhadith (mempunyai hafalan hadis yang kuat). ${ }^{21}$

Keenam, Abū Bakr b. Abi Shaybah. Sanadnya terbukti tersambung dengan Yazid b. Hārūn. ${ }^{22}$. Sedangkan para ulama seperti Aḥmad b. Hanbal, al-' $\mathrm{C} j \overline{\mathrm{i}} \bar{i}$, al-Nasa $\overline{\mathrm{i}}$, dan al-Dhahabi secara umum meyakini bahwa dia adalah orang yang thiqqah. ${ }^{23}$

Ketujuh, Ibn Majah. ${ }^{24}$ Dia dilahirkan pada tahun 209 H. dan wafat pada tahun $273 \mathrm{H}$, tepatnya pada usia 64 tahun. ${ }^{25}$ Dari segi sanad, dia terbukti bersambung dengan perawi sebelumnya yakni Abū Bakr b. Abi Shaybah. ${ }^{26}$ Dari segi kualitas, dia termasuk perawi yang thiqqah, hal ini dibuktikan dengan penilaian ulama kepadanya, seperti (1) Abu Hāatim yang menyebutkannya sebagai thiqqab; (2) al-Dārūqutnī menilainya thiqqab; (3) Ibn Ḥajar al-'Asqalāni: hạafiz̧; (4) Abū Ya'lā: thiqqat kabir (sangat dipercaya). ${ }^{27}$

b. Naqd al-Matn

Dalam kutub al-tis'ah (kitab hadis muktabar yang berjumlah sembilan), hadis tentang ruwaybidah setidaknya ditemukan dua versi. Pertama, yang diriwayatkan oleh Abū Hurayrah dalam Sunan Ibn Mäjah. Kedua, yang diriwayatkan oleh Abū Hurayrah dalam Sunan Imam Aḅmad. Redaksi hadis dalam Ibn Majah telah ditulis sebelumnya, adapun redaksi dalam penuturan Imam Aḥmad b. Hanbal yakni ${ }^{28}$ :

\footnotetext{
${ }^{20}$ Al-Mizzi, Tabdhīb al-Kamāl, vol. 27, 214.

${ }^{21}$ Ibid.

22 Al-'Asqalāni, Tahdhīb al-Tabdhīb, vol. 4, 156-177.

${ }^{23}$ Ibid., 179-182.

${ }^{24}$ Al-Qazwayni, Sunan, vol. 1, 6.

${ }^{25} \mathrm{Al}$-Mizzi, Tahdhīb al-Kamāl, vol. 28, 166.

26Ibid., 180-189.

27Ibid., 190.

${ }^{28}$ Aḥmad b. Hanbal, Musnad Aḥmad b. Hanbal (Riyad: Bayt al-Afkār, 1998), 312.
} 


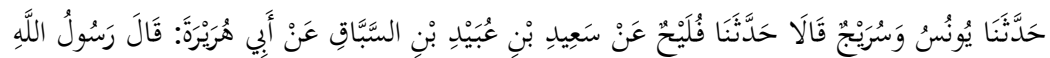

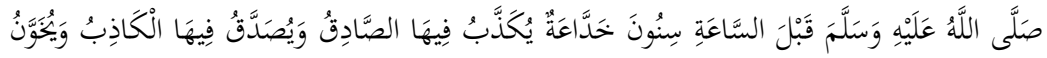

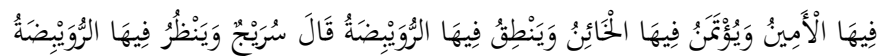

"Telah menceritakan kepada kami Yūnus dan Surayj, mereka berkata: telah menceritakan kepada kami Fulayh dari Sa $\bar{i} d$ b.'Ubayd al-Sabbāq dari Abu Hurayrah, dia berkata: Rasulullah bersabda: "Sebelum hari kiamat akan datang tahun-tahun yang penuh tipu muslihat, orang yang jujur didustai sedang pendusta dipercaya, orang yang amanah dikhianati, sedang pengkhianat diberi amanah, dan ruwaybidab akan berbicara." Surayj berkata: "Pada tahun tersebut orang-orang ruwaybidah akan melihat."

Secara tekstual, kedua hadis tersebut tidak ditemukan perbedaan yang signifikan. Kedua hadis memiliki alur dan nilai inti yang sama, yakni merepresentasikan situasi yang tidak diinginkan. Hadis dalam Sunan Ibn Majah menggunakan redaksi "Akan datang kepada manusia tahun-tahun yang penub dengan penipuan". Sedangkan dalam Musnad Imām Aḥmad dengan redaksi "sebelum hari kiamat". Setelah kalimat tersebut, kedua hadis menunjukkan ketimpangan sosial di masyarakat terkait etika yang berkembang saat itu.

Adapun dari aspek gramatikal, kata ruwaybidah dalam hadis yang pertama, menunjukkan makna yang lebih jelas daripada hadis yang kedua, dengan menggunakan redaksi "Orang bodoh yang turut campur dalam urusan masyarakat luas." Dengan penyebutan hadis yang serupa, aspek matannya, menjadikan matan hadis Sunan Ibn Mäjah menjadi lebih kuat kualitasnya, sekaligus dapat dipastikan, hadis yang dinukil oleh Ibn Majah bernilai shahih dan dapat dijadikan pedoman dalam memaknai ruwaybidah.

Meski terdapat dua perawi yang memiliki kualitas di bawah thiqqah, yakni Ishāa b. Abi al-Furāt yang berkualitas daif, dan 'Abd alMālik b. Qudāmah yang bukan termasuk perawi yang kuat hafalannya, di sana terdapat riwayat lain yang menguatkan hadis tersebut dan disertai dengan mayoritas perawi yang meriwayatkan hadis bernilai thiqqah, maka hadis tersebut termasuk dalam kategori hadis marfu" yang bisa diamalkan.

Adapun dalam keterangan di Kitab Sunan Ibn Mäjah, dia memasukkan hadis tentang ruwaybidah ke dalam hadis sahih. ${ }^{29} \mathrm{Hal}$ ini sekaligus menjadi indikator kuat bahwa hadis ini layak untuk dipahami

${ }^{29}$ Al-Qazwayni, Sunan Ibn Mäjab (Riyad: Dār al-Khaḍrā', 2015), 623. 
dan dijadikan pedoman dalam menyikapi permasalahan yang ada di era modern, atau dalam redaksinya menggunakan kata sanawat alkbudda'at (masa-masa penuh tipu muslihat). Terlebih, hadis ini diklasifikasikan dalam bab fitnah, yang menuntut adanya upaya memahami konteks lebih mendalam disertai dengan merelasikan antara budaya, adat kebiasaan dan norma-norma yang berkembang di masyarakat.

\section{Memahami Makna Ruwaybị̣ah}

Hadis ruwaybidah termasuk ke dalam kategori hadis prediktif. Hal tersebut ditandai oleh penggunaan kata سَّبَأْنِ yang menuntut makna mustaqbal (yang akan datang). Lebih rinci, bahwa hadis ini mempunyai makna denotatif yang mengarah pada prediksi yang buruk di masa mendatang, sebagaimana yang tergambar dalam frase سَنَوَاتُ خحَدَّاعَاتُ yang bermakna "tahun-tahun yang penuh dengan tipu

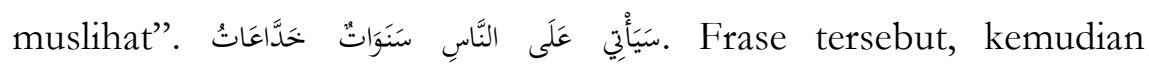
dijelaskan oleh al-Suyūṭi bahwa tahun-tahun penipuan ialah masa penuh dengan tipu daya dan tipu musilhat. Pada tahun-tahun tersebut, banyak terjadi hujan, sedangkan tempat yang tinggi, tempat untuk menyelamatkan dari banjir, sangatlah sedikit, dan hal tersebut bisa membahayakan kehidupan manusia. ${ }^{30}$

Melihat penjelasan dari al-Suyūtị, dia cenderung menggambarkan kerusakan ekologis, bukan keburukan sifat manusia. Padahal, kata ruwaybidah merupakan bentuk tasghir dari kata rabidah yang berarti orang lemah yang minus terhadap perkara-perkara yang luhur. ${ }^{31}$ Tentunya, hal tersebut sangat berkaitan dengan posisi manusia sebagai wakil Tuhan di bumi. Masih terkait frase "tahuntahun yang penuh dengan penipuan" dijelaskan bahwa pada masa tersebut nampak secara jelas tipu daya dari hati seseorang, seakanakan itu adalah sebuah kebenaran, sampai-sampai setiap orang terkelabuhi oleh tipu daya tersebut. ${ }^{32}$

Kondisi yang timpang (baca: instabilitas publik),tergambarkan melalui kata khuddáat (penipuan) yang sekaligus bentuk kalimatnya berupa mubālaghah (hiperbolik). Dalam kajian bahasa arab, mubālaghah menunjukkan makna "lebih". Oleh karena itu, frase tersebut,

\footnotetext{
${ }^{30}$ Jalāl al-Dìn al-Suyūtị, Shurūh Sunan Ibn Mäjah (Beirut: Bayt al-Afkār, 2007), 1474.

31 Munawwir, Kamus Al-Munawwir, 465.

${ }^{32}$ Al-Suyūtị, Shurūh, 1474.
} 
memberikan makna bahwa kebohongan yang terjadi benar-benar merajalela. ${ }^{33}$ Yang perlu untuk digaris bawahi di sini adalah bahwa kebohongan yang terus-menerus dilakukan akan dianggap sebagai sebuah kebenaran. Jika hal itu terjadi, maka dunia akan penuh dengan manipulasi dan penipuan. Dan pada saatnya, inilah yang disebut oleh Rasulullah dengan redaksi sanawät al-khuddā at dalam hadis ruwaybidah tersebut.

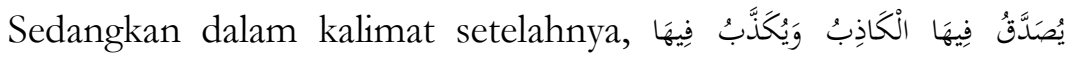

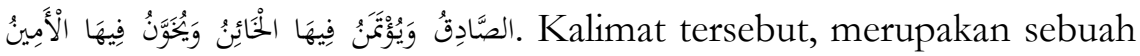
permisalan terkait dengan adanya perubahan keadaan di dunia yang mengarah pada ketimpangan sosial; ketika pendusta dan pembohong itu menyebar dan keduanya dianggap sebagai orang yang benar. Orang yang jujurjustru dianggap dusta,orang amanat akan diingkari; karena pada zaman ruwaybidah, kedua orang tersebut ditentang dan orang-orang pada umumnya lebih memilih orang yang bodoh. Mereka mengambil ulama dari golongan orang jubbäl (bodoh), dan mengangkat pemimpin yang tidak adil. ${ }^{34}$

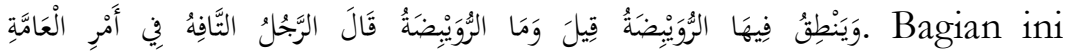
merupakan narasi spesifik, terkait tanda-tanda munculnya tahuntahun penipuan, yang dalam riwayat Imam Ahmad dijelaskan sebagai tanda-tanda sebelum hari kiamat. ${ }^{35}$ Kata utama dalam kalimat ini adalah al-ruwaybidah. Dalam konteks hadis tersebut, para sahabat tidak langsung paham tentang makna ruwaybidah yang dimaksud oleh Nabi. Kemudian dia memperjelas, bahwa yang dimaksud ruwaybidah adalah al-rajul al-täfih (orang bodoh). Kemudian al-Suyüți menjelaskan, bahwa orang bodoh dalam kalimat tersebut adalah orang yang tercela, hina, rendah, kotor dan kasar. Adapun kata ruwaybidah merupakan bentuk kata benda tasghir dari kata rabidah, yakni orang lemah yang ikut mengurusi urusan umat. ${ }^{36}$

Sedangkan menurut al-Sindi, bahwa "ikut campur" yang dimaksud dalam hadis tersebut berkaitan dengan berbicara atau menyampaikan informasi. Sedangkan al-täfib/al-hääir bermakna yasir

\footnotetext{
33 Abū Husayn al-Sindi, Sunan Ibn Mājah bi Sharh al-Sindì wa Miṣbāḥ al-Zujäjah, vol. 4(Beirut: Dār al-Ma'rifah), 377.

34'Alā' al-Dīn b. Mughlațāīi, Sharḅ Sunan Ibn Mājah (Riyad: Maktabat Nizār Muṣtafāa al-Bāz, 1999), 417.

35Ibn Hanbal, Musnad, 312.

${ }^{36}$ Mughlațāi, Sharh Sunan, 417.
} 
yakni sedikit ilmunya. ${ }^{37}$ Dari penjelasan tersebut, dapat disimpulkan bahwa ruwaybidah adalah orang yang tidak punya ilmu namun memberikan informasi kepada orang lain.

Sebenarnya, pemaknaan tentang ruwaybidah juga dapat ditelusuri melalui salah satu hadis sahabat Anas yang meriwayatkan ${ }^{38}$ :

$$
\text { والرجل التافه الرذيل والحقير اللهر في الأمم قبلنا قال الملك في صغاركم والفاحشة في كباركم والعلم في رذالتكم }
$$

"Wahai Rasulullah,apa yang nampak di umat-umat setelah masa kami (Sahabat)? Rasulullah menjawab: Kekuasaan di masa kecil kalian, dan keburukan di masa dewasa kalian, ilmu dalam kehinan kalian, dan orang-orang yang pandir(tidak tau), hina dan tercela."

Penjelasan tersebut, memperkuat makna dasar dari kata ruwaybidah yang merujuk kepada manusia yang tidak memiliki kemampuan, lemah dan hina. Maka, bisa digarisbawahi bahwa hadis ini pada hakikatnya mencoba memberikan penjelasan penting terkait situasi dan kondisi yang akan dihadapi manusia di masa mendatang, yang berkaitan dengan dua nilai penting, yakni kebohongan dan kualitas manusia di masa sekarang ini. Oleh karena itu, memaknai lebih jauh terkait makna ruwaybidah melalui multi perspektif menjadi penting untuk dilakukan.

Adapun secara situasional, hadis tersebut sebenarnya mengandung dua makna pokok yakni: (1) Memberikan arahan supaya berhati-hati kepada sosok yang dijuluki ruwaybidah. Pertanyaan kemudian adalah siapakah ruwaybidah di era modern? apakah hanya bisa ditelusuri berdasarkan riwayat, bahwa ruwaybidah berkaitan dengan dajjal $?^{39}$ Tentu hal ini akan memunculkan polarisasi makna, karena hakikat dari hadis ini lebih sesuai jika dimaknai dengan situasi ketimpangan sosial dimana kebenaran dan kebohongan tidak bisa dibedakan lagi; (2) Menginformasikan bahwa nanti akan ada masamasa kerusakan moral dan pemutar-balikkan fakta atau kenyataan, dimana orang yang jujur tidak dipercayai, sedangkan pendusta malah dijadikan orang yang paling benar. Maka, hadis ini bisa dipahami melalui dua nalar. Pertama, nalar bayan $\bar{i}$ yang cenderung lebih tekstualis

\footnotetext{
${ }^{37} \mathrm{Al}-$ Sindi, Sunan Ibn Mäjah, vol. juz 4, 377.

${ }^{38}$ Al-Suyūtị, Shurūh Sunan, 1474.

39 Aḥmad al-Ṭabarāini, Mu'jam al-Kabìr, vol. 8 (Kairo: Maktabat Ibn Taymìah), 153.
} 
dan menggunakan riwayat-riwayat. Kedua, nalar burban $\bar{i}$ yang cenderung lebih menempatkan rasio untuk memaknai teks. ${ }^{40}$

\section{Konteks Sosio-Historis Hadis Ruwaybidah}

Beberapa dekade terakhir, kajian multi-disiplin mendapatkan perhatian yang semakin besar. Aspek empirik yang meliputi dimensi sosial-kemasyarakatan menjadikan kajian yang tidak sebelah mata mendapatkan prioritas dalam menelaah problem kekinian. Termasuk kajian hadis yang dielaborasi dengan perangkat ilmu-ilmu sosial. Membongkar makna yang terkandung dalam hadis melalui penyatuan pecahan-pecahan sejarah sangatlah penting, sebab kesejarahan di masa Nabi dengan kenyataan di era modern sangatlah berbeda. Dengan upaya tersebut, dapat diketahui latar belakang kemunculan sebuah hadis, sekaligus dapat dipahami cara implementasinya di era modern. ${ }^{41}$ Dalam menelusuri dimensi kesejarahan, akan mengarah kepada dua aspek yakni:

a. Aspek Mikro ${ }^{42}$

Melihat konteks mikro dalam suatu hadis, biasanya selalu berkaitan dengan asbāb wurüd al-ḩadith (historisitas munculnya hadis). Secara etimologis, asbab al-wurüd dapat diartikan tali atau penghubung sampainya sesuatu, sedangkan secara terminologis dapat diartikan

\footnotetext{
40 Setidaknya terdapat tiga penalaran dalam upaya menemukan ilmu pengetahun,

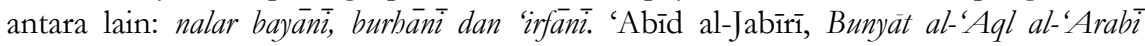
(Beirut: Markaz Dirāsat al-Waḥdah al-'Arabìyah, 1989), 315.

${ }^{41}$ Benny Afwadzi, "Membangun Integrasi Ilmu-ilmu Sosial dan Hadis Nabi”, Jurnal Living Hadis, Vol. 1, No.1, (2016), 110.

${ }^{42}$ Konteks Historis suatu teks, menurut sejarah terbagi menjadi 2, konteks mikro dan makro. Secara mikro, asbāb wurüd al-ḥadith didefinisakan oleh para ulama dengan peristiwa-peristiwa yang direspon oleh Rasulullah melalui sabda-sabdanya. Peristiwa yang dimaksud di sini bisa berupa pertanyaan seorang sahabat Nabi tentang sesuatu atau berupa perilaku seseorang yang kemudian dijawab atau direspons oleh Nabi. Dan peristiwa-peristiwa tersebut hanya dapat diketahui berdasarkan periwayatan. Mu'ammar Zayn Qadafy, Buku Pintar Sababun Nuzul Dari Mikro Hingga Makro: Sebuah Kajian Epistemologis (Yogyakarta: In AzNa Books, 2015), IX-X. Sedangkan konteks makro atau dalam kajian hadis merujuk pada hadis-hadis yang tidak memiliki sebab khusus, mempunyai arti bahwa secara makro, asbāb wurüd alhadithdipahami sebagai segala situasi dan kondisi yang ada di Arab dan bangsabangsa lain di sekitarnya yang hidup pada abad ke-7 dan mendapatkan respons dari hadis Nabi, yang mana model seperti ini dianggap oleh Wali Allāh al-Dihlāwi

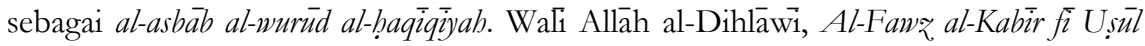
al-Tafsìr (Kairo: Dār al-Ṣaḥwah, 1987), 31. Bandingkan dengan Arifuddin Ahmad, Paradigma Baru Memahami Hadis Nabi (Jakarta: Insan Cemerlang), 238.
} 
sebagai sebab-sebab yang melatar-belakangi munculnya suatu hadis. ${ }^{43}$ Namun, jika merujuk pada redaksi hadis tentang ruwaybidah yang diriwayatkan oleh Abū Hurayrah, dalam Sunan Ibn Mäjah, secara ekplisit tidak dijelaskan sama sekali penyebab dituturkannya hadis tersebut.

Di sisi lain, melalui redaksi hadis tersebut, dapat dipahami bahwa hadis ini dilatar-belakangi oleh diri Nabi yang ingin mengingatkan umatnya bahwa dunia adalah tempat yang penuh dengan cobaan, maka berhati-hatilah bagi orang yang ingin memelihara dirinya dan agamanya. Sehingga tidak ditemukan fitnah tersebut, dan selamat darinya. ${ }^{44}$

Oleh karena itu, hadis ini dapat dipahami sebagai bentuk peringatan dari Nabi akan datangnya masa-masa yang buruk di akhir zaman, maka sikap yang bisa dilakukan adalah menghindari sosok yang disebut oleh Nabi dengan nama ruwaybidah. Hal ini sekaligus berimplikasi bahwa meninjau sosok tersebut di era modern menjadi hal yang penting, bersamaan dengan identifikasi bentuk penyampaian kebohongannya.

b. Aspek Makro

Secara historis, bahwa kehidupan di Arab ada abad ke-7 masih erat kaitannya dengan perkembangan Islam. ${ }^{45}$ Maka tidak heran, jika Nabi Muhammad ketika mendeskripsikan sesuatu, termasuk hadis prediktif, tidak akan melebihi batas kemampuan audience yang pada saat itu merupakan para sahabat-sahabat Nabi Muhammad. Sepertihalnya ketika menjelaskan bahaya perempuan di masa mendatang, dia hanya menggunakan redaksi fitnah. Sebagaimana dalam hadis yang diriwayatkan oleh Imam al-Bukhāri ${ }^{46}$ :

$$
\text { الرجال من السامة رضي الله عنه قال: قال رسول الله صلى الله عليه وسلم: ماتركتُ بعدي فتندً أضرَّ على النى }
$$

"Dari Usāmah berkata: Rasulullah bersabda: “Aku tidak meninggalkan sesudahku suatu fitnah yang lebih berbahaya selain dari fitnah kaum perempuan."

\footnotetext{
43 Abdul Mustaqim, Ilmu Ma'anil Hadits: Paradigma Interkoneksi (Yogyakarta: Idea Press, 2016), 40.

${ }^{44}$ Mughlatăi, Sharb Sunan, 418.

45 'Abd al-Mālik b. Hishām, Al-Sìrah al-Nabawìyah (Beirut: Dār Ibn Hazm, 2009).

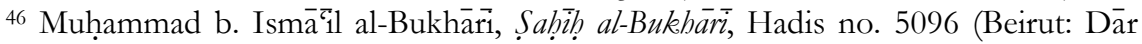
Ibn Kathir, 2002), 1299.
} 
Kata fitnah dalam redaksi hadis di atas tentu memunculkan polarisasi makna, terlebih jika dikaitkan dengan dinamika perkembangan kultur budaya di era modern. Rasulullah mencoba memberikan gambaran yang ringkas terkait prediksi tentang adanya sesuatu di masa mendatang. Penulis menduga bahwa model hadis seperti ini ditujukan agar umat Islam di masa mendatang lebih bisa menggali makna hadis berdasarkan asas maslahat. Dalam kasus yang sama, juga dapat ditemukan dalam redaksi hadis ruwaybidah, meski secara deskriptif hadis tersebut sudah dijelaskan oleh Nabi sendiri. Namun masih terdapat sekat-sekat yang mengakibatkan kebuntuan dalam memaknai hadis ruwaybidah dengan semangat yang selaras dengan kemajuan zaman.

Dalam konteks sejarah Arab, masing-masing suku memiliki nilai kebajikan tersendiri. Nilai-nilai kebajikan tertinggi orang Arab seperti yang tercermin dalam puisi-puisi kaum pagan yang diungkapkan dalam istilah murüah (kewibawaan) dan 'ird (kehormatan). Unsurunsur yang terdapat dalam murüah adalah keberanian, loyalitas, dan kedermawanan. Keberanian diukur berdasarkan jumlah peperangan yang pernah diikuti. Kedermawanan tampak dari kesediaannya mengorbankan untanya untuk menyambut tamu atau untuk kepentingan orang miskin dan yang membutuhkan bantuan. ${ }^{47}$

Lebih spesifik lagi, setelah Islam datang bersamaan dengan Nabi, pondasi kebajikan-kebajikan Arab lebih terstruktur dan mempunyai bentuk tersendiri dalam bingkai ajaran Islam. Sudah umum diketahui, bahwa beberapa sahabat dekat Rasulullah mempunyai gelar mulia untuk menunjukkan kehormatan yang dimilikinya, sebut saja seperti Abū Bakr yang mendapat gelar al-Siddiq, 'Umar yang bergelar al-Farüq, 'Uthmān sang penderma dan Ali sebagai pintu ilmu. Nilai-nilai kebaikan seperti itu yang diharapkan oleh Nabi terimplementasi dari setiap jiwa umat Islam.

Adapun terkait hadis ruwaybidah, hal ini secara jelas menunjukkan suatu sifat dan budaya yang tidak dimiliki oleh bangsa Arab, apalagi berdasarkan tuntutan agama. Namun tidak dipungkiri, bahwa sejak masa Nabi, para pendusta yang menyebarkan kabar buruk (baca: munafik) menjadi trauma tersendiri bagi diri Nabi. Hal ini dapat dibuktikan dengan banyaknya pembelot yang melakukan pengkhianatan kepada Islam. Sebagaimana dalam kasus perang Uhud,

47 Philip K. Hitti, History of the Arabs, Terj. Cecep \& Dedi (Jakarta: Zaman, 2018), 119. 
terdapat seorang munafik bernama 'Abd Allāh b. Ubayy yang menarik diri dari pasukan muslim dan kembali ke Madinah. Kemudian, terdapat pengkhianatan yang dilakukan oleh Bani Nadīr yang melakukan pengingkaran terhadap piagam Madinah. Bahkan, mereka berkomplot untuk membunuh Nabi Muhammad. ${ }^{48}$

Berdasarkan argumen sejarah di atas, maka pemahaman Rasulullah tentang kerusakan dan ketimpangan sosial itu sangat mungkin terkonstruksi dari pengalaman Nabi yang merasakan kerugian dari para pembohong yang merugikan Islam. Karena, penipuan-penipuan yang terjadi sudah berlangsung sejak zaman Rasulullah, dan hal tersebut ditandai dengan kemunafikan seseorang. Sedangkan penipuan yang diprediksikan Nabi sebelum adanya kiamat ditandai oleh sosok ruwaybidah ini. Jika melihat dari redaksi hadis sebelumnya yang menggunakan bentuk mubälaghah, mengindikasikan bahwa penipuan yang terjadi dalam deskripsi hadis ruwaybidab lebih parah daripada yang ada di zaman Nabi.

Pada dasarnya, narasi yang ingin disampaikan Nabi adalah melalui gambaran situasional di masa mendatangyang kemudian merujuk sebab adanya ketimpangan yang terjadi berdasarkan sosok yang disebut ruwaybidah ini. Padahal, hadis ruwaybidah, dideskripsikan di beberapa riwayat sebagai sebuah fitnah akhir zaman yang dikaitkan dengan sosok yang bernama Dajjal. ${ }^{49}$ Pembawaan tokoh ini, kemudian dideskripsikan oleh Nabi sebagai orang yang membawa kabar dusta. Pemisalan yang dilakukan oleh Rasulullah hanya berdasarkan informasi yang dibawa, dan bisa jadi hanya berdasarkan pengalaman Nabi tentang kerugian yang disebabkan adanya pembohong kala itu. Maka, identifikasi seperti ini di zaman dahulu sangatlah mudah untuk ditemukan. Karena, tanda yang dijadikan tolak ukur dalam penetapan penokohan ruwaybidah hanya berdasarkan kemampuan saja. Sedangkan, media informasi di era sekarang sangatlah beragam dan tentunya sangat susah untuk menemukan orang-orang yang dijuluki ruwaybidah.

48 Faisal Ismail, Sejarah \& Kebudayaan Islam: Periode Klasike (Abad VII-XIII M) (Yogyakarta: IRCiSoD, 2017), 172.

${ }^{49} \mathrm{Al}-$ Tabarāni, Mu jam al-Kabir, vol. 8, 153.

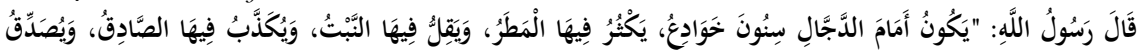

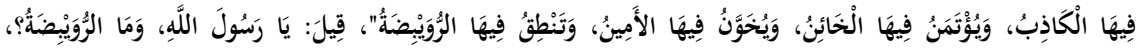




\section{Relevansi Hadis Ruwaybidah dengan Permasalahan Sosial}

Hadis menempati urutan kedua sebagai sumber hukum Islam. ${ }^{50}$ Hal ini menjadikan umat muslim berkewajiban merujuk hadis jika memang tidak ditemukan jawaban atas permasalahan yang ada dalam Alquran. Pemahaman hadis di era modern diperlukan untuk merespon perkembangan zaman yang berlangsung secara cepat, beserta dengan harapan bahwa hadis Nabi dapat menjadi sebuah solusi atas beberapa polemik yang masih belum mendapatkan jawaban saat ini. ${ }^{51}$

Namun pada kenyataannya, hadis tidak cukup dipahami secara tekstual, karena hadis selalu terikat dengan ruang dan waktu ketika disabdakan. ${ }^{52}$ Maka, upaya pembacaan komprehensif yang mempertimbangkan aspek sosio-historis menjadi sebuah keniscayaan. Lebih-lebih, upaya tersebut harus selalu digalakkan terutama ketika hendak memahami hadis prediktif.

Adapun korelasi hadis ruwaybidah dengan era digital, yakni bahwa keberadaan hadis prediktif selalu memiliki nilai penting sebagai sebuah gambaran yang akan dihadapi atau yang sudah dihadapi oleh umat Islam setelah masa Rasulullah. Maka, selalu terdapat korelasi antara hadis prediktif dengan permasalahan kontemporer. Hadis ruwaybidah secara umum menginformasikan ketimpangan sosial setelah masa Rasulullah, hal tersebut tergambarkan dengan narasi Nabi yang menyatakan "pendusta akan dibenarkan, sedangkan orang yang jujur malah didustakan"dan kemudian disertai dengan kemunculan ruwaybidah. Kasus tersebut sebenarnya sangat sesuai dengan fenomena yang terjadi akhir-akhir ini. Di sisi lain, tidak jarang ditemukan orang-orang yang berbicara tentang sesuatu sedangkan dirinya sendiri tidak mengetahui tentang apa yang dibicarakan. Tentu hal ini menjadi bukti kuat bahwa prediksi Nabi tentang munculnya ruwaybidah benar adanya.

Bahkan, kemunculan term hadith (pembicaraan)memperlihatkan sebuah simbol bahwa sejarah manusia tidak lepas dari keberagaman bentuk komunikasi, antara baik dan buruk. Begitu juga dengan keberadaan orang-orang pendusta yang meskipun bukan menjadi

\footnotetext{
50 M.M. Azami, Hadis Nabi dan Sejarah Kodifikasinya, Terj. Ali Musthofa Ya'qub (Jakarta: Pustaka Firdaus, 2018), 27.

${ }^{51}$ Muhammad Nurudin, Aktualisasi Pemahaman Hadis Hukum dalam Kehidupan Global, dalam Riwayah, Vol. 1, No. 1 (2015), 40.

52 Moh. Nailul Muna, "Ragam Pemaknaan Jihad Dalam Kitab Fatḥ al-Bāri dan Irshād al-Sär”’, dalam Mutawatir: Jurnal Keilmuan Tafsir Hadis, Vol. 7, No. 2 (2017), 361.
} 
watak kabilah-kabilah Arab, namun hal tersebut tidak bisa luput dalam sejarah panjang perkembangan Islam. Kenyataan tersebut membawa sebuah opini baru, bahwa keberadaan ruwaybidab dapat diidentifikasi sejak zaman dahulu, meski hadis utama dalam kajian ini merupakan hadis prediktif yang meniscayakan kebenaran pembuktian di masa mendatang, tidak serta merta menegasikan sejarah yang mempunyai peran penting untuk melihat pola pemahaman Rasulullah terhadap sosok ruwaybidah. Penggambaran sosok ruwaybidah sungguh sangat sederhana, merujuk kepada penyampaian informasi yang tidak selaras dengan kemampuan, secara langsung menjadikan si pembicara termasuk tokoh ruwaybidah. Padahal, identifikasi seperti ini jelas tidak efektif di masa modern.

Terlebih, bahwa pola komunikasi di era modern sangatlah kompleks, disebabkan karena kecanggihan teknologi yang mampu menyentuh hal-hal yang tidak terfikirkan sebelumnya. Teknologi komunikasi, dapat membawa manusia kepada masa pasca-industri, teknologi komunikasi juga dapat mempermudah gerak manusia, dan menghilangkan batas waktu dan tempat. Demikian dampak positif dari keberadaan teknologi komunikasi. Di sisi lain, dampak negatifnya adalah informasi yang disajikan menghilangkan norma-norma budaya yang menjadi panduan etika dalam komunikasi. ${ }^{53}$

Meski demikian, bukan berarti penelusuran tentang ruwaybidah harus dibekukan, terlebih komunikasi dalam kehidupan manusia menempati posisi yang penting. Melalui komunikasi, setiap individu memiliki kesempatan untuk berpartisipasi dalam kehidupan kemasyarakatan dengan individu yang lainnya. Bahkan menurut Habermas, bahwa komunikasi menjadi sebuah usaha untuk mencapai kesepakatan bersama dalam memecahkan berbagai persoalan yang ada. ${ }^{54}$ Maka, penelusuran tentang makna ruwaybidah lebih layak untuk dibaca secara kontekstualis.

\section{Reinterpretasi Makna Hadis Ruwaybidah}

Kata ruwaybidah memiliki akar kata dari bahasa arab yaitu "rabada" yang artinya menderum sebagaimana binatang-binatang yang

\footnotetext{
53 Mohammad Zamroni, "Perkembangan Teknologi Komunikasi dan Dampaknya terhadap Kehidupan”, Jurnal Dakwah, Vol. 10, No. 2 (2009), 209.

${ }^{54}$ Muh. Syawir Dahlan, "Etika Komunikasi dalam Al- Qur'an dan Hadis", dalam Jurnal Dakwah Tabligh, Vol. 15, No, 1, (2014), 121.
} 
menderum. ${ }^{55}$ Kemudian, kata ini juga dapat memunculkan makna penggembala yang biasanya menggunakan kata rä ín. Adapun secara spesifik bahwa kata ruwaybidah diambil dari kata berbentuk tasghir, rabidah yang berarti orang yang lemah terhadap perkara-perkara yang luhur. ${ }^{56}$ Penggunaan bentuk tasghir dalam kajian gramatikal bahasa Arab menuntut adanya arti mengerdilkan atau menjadikan kecil. ${ }^{57} \mathrm{Hal}$ ini menunjukkan bahwa ruwaybidab bukan hanya orang-orang yang bodoh namun dipertegas oleh Nabi sebagai orang yang rendah dan kerdil dengan pemilihan kata berbentuk tasghir.

Aspek gramatikal di atas menunjukkan bahwa sosok ruwaybidah selalu berkonotasi dengan hal-hal yang buruk. Namun, hadis ini tidak sesuai jika dimaknai secara parsial saja. Secara umum hadis ini menarasikan adanya ketimpangan sosial yang akan melanda umat Rasulullah di masa mendatang. Hal tersebut digambarkan dengan adanya penipuan dimana-mana yang mana kebohongan-kebohongan tersebut dianggap benar.

Sebenarnya, terdapat dua nilai pokok yang dapat diambil dari hadis tentang ruwaybidah, yaitu tentang kebohongan dan tentang kemampuan. Jika dua hal tersebut disintesiskan, bahwa seseorang yang tidak mengetahui tentang suatu perkara maka dia mempunyai peluang yang lebih besar untuk melakukan kebohongan terhadap hal tersebut daripada orang yang paham tentang suatu perkara.

Dalam melakukan upaya reinterpretasi, perlu mengacu kepada aspek sejarah yang telah dipaparkan di bagian awal, bahwa adanya golongan munafik di masa Rasulullah, bisa menjadi sumber pemahaman Rasulullah untuk mendeskripsikan ketimpangan sosial di masa mendatang dengan merujuk golongan pembohong sebagai penyebab permasalahan sosial. Padahal, kenyataan yang ada sekarang bahwa ketimpangan sosial yang terjadi sangatlah banyak dan disebabkan oleh banyak faktor. Oleh karena itu, hadis ini dapat dipahami melalui dua nalar: bayāni dan burbani $\bar{i}^{58}$

\footnotetext{
55 Abī Fạ̣l Muḥammad b. Manzūur, Lisān al-'Arab (Kairo: Dār al-Ma'ārif, 1119 H.), 1558.

${ }^{56}$ Munawwir, Kamus Al-Munawwir, 465.

${ }^{57}$ Bahā' al-Din 'Abd Allāh b. 'Aqīil, Terjemah Alfiyyah Syarah ibn Aqil (Bandung: Sinar Baru Algensindo, 2015), 880.

58 'Abīd al-Jabīrī, Takwīn al-'Aql al-'Arabì (Beirut: Markaz Dirāsat al-Waḥdah al'Arabijah, 1989), 106.
} 
Jika menggunakan nalar bayani, ketimpangan yang terjadi memang benar dilakukan oleh orang-orang pembohong termasuk di dalamnya ruwaybidah. Sedangkan melalui nalar burbāin, ketimpangan yang terjadi secara luas dapat disebabkan oleh siapa saja yang melakukan sesuatu tidak berdasarkan kemampuan yang dimilikinya. Berkaitan dengan hal tersebut, maka segala bentuk perbuatan, bukan hanya melakukan kebohongan saja, tercakup dalam term ruwaybidah. Ketika seseorang insinyur menyebarkan informasitentang sesuatu yang tidak dia ketahui, terkait nilai-nilai spiritual, hal ini tidak diperbolehkan dalam kacamata hadis ruwaybidah. Begitu juga ulama yang tidak memiliki kapabilitas di bidang politik maka dia terlarang untuk ikut serta dalam perpolitikan, meski ulama tersebut mempunyai citra yang baik dan populer di masyarakat.

Dengan kacamata bayani ini, memaknai ruwaybidah dalam ranah sosial bukan hanya melarang seseorang membicarakan hal yang tidak dia kuasai saja, di sisi lain dia juga dituntut menyampaikan segala sesuatu yang benar berdasarkan pemahaman objektif atas sesuatu. Maka tidak cukup makna ruwaybidah dibatasi dengan kemampuan seseorang dalam bidang tertentu, namun harus dibarengi dengan sikap jujur dalam menyampaikan sesuatu berdasarkan kebenaran yang dipahami melalui keilmuan yang relevan. Dan hal tersebut yang tergambar dalam redaksi hadis "pendusta dibenarkan dan orang yang jujur malah didustakan".

Alquran telah memberikan ancaman yang nyata terhadap orang yang tidak menyampaikan kebenaran, padahal dia mempunyai kemampuan di tentang hal itu. Dalam QS. Al-A'raf [7]: 179, disebutkan:

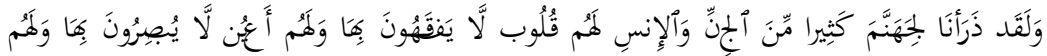

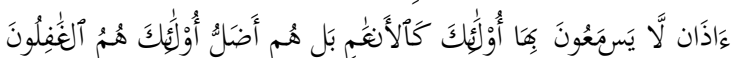

Dan sesungguhnya Kami jadikan untuk (isi neraka Jahannam) kebanyakan dari jin dan manusia, mereka mempunyai hati, tetapi tidak dipergunakannya untuk memahami (ayat-ayat Allah) dan mereka mempunyai mata (tetapi) tidak dipergunakannya untuk melihat (tanda-tanda kekuasaan Allah), dan mereka mempunyai telinga (tetapi) tidak dipergunakannya untuk mendengar (ayat-ayat Allah). Mereka itu sebagai binatang ternak, bahkan mereka lebih sesat lagi. Mereka itulah orang-orang yang lalai.

Adapun dari penalaran burbāni, hadis ruwaybidah bisa memiliki beragam bentuk di era modern. Adapun beberapa gambaran 
ruwaybidah di era modern, antara lain: (1). Orientalis yang dengan sengaja ingin merusak agama Islam; (2) Penyebar hoax; (3) Pendusta; (4) Pengujar kebencian; (5) Pengacara yang berbicara bukan demi kebenaran; (6) Ulama yang mendakwahkan sesuatu berdasarkan hawa nafsunya dan bukan karena kebenaran; (6) Artis atau public figure yang menyimpang dari etika komunikasi yang baik. Klasifikasi tersebut belum mencakup segala yang ada, namun setidaknya sudah mewakili makna pokok dari ruwaybidah di era modern.

Selain itu, hadis ruwaybidah juga memberikan nilai pokok dari etika komunikasi yang baik, yakni "berbicara sesuai dengan keahlian", artinyaterdapat larangan berbicara terhadap sesuatu yang tidak dipahami. Kalaupun maknanya diperluas, maka lakukanlah sesuatu yang menjadi keahliannya, dan jangan lakukan sesuatu yang bukan menjadi keahliannya. Hal ini sangat mungkin bertentangan dengan fenomena yang terjadi di era modern, dimana setiap orang ingin mengambil peran di setiap ranah yang terkadang ia tidak mempunyai kemampuan di dalamnya.

\section{Makna Hadis dalam Rumusan Kode Etik}

Etika komunikasi publik bisa didefinisikan sebagai filsafat moral yang mempelajari dan mengatur tata sikap serta perilaku pers, penyiaran, dan media massa dalam jaringan (online) internet (media siber), sejak tahap perencanaan peliputan sampai dengan pemuatan, penyiaran, dan penayangan berikut dampaknya kepada khalayak pembaca, pendengar, dan pemirsa. Sesuai dengan misi dan fungsi yang dimilikinya, media massa harus menjadi penuntun perilaku sosial publik yang berpegang teguh kepada kaidah moralitas dan etika profesi. $^{59}$

Urgensi dari etika komunikasi massa berkaitan dengan tingkat keluasan penerima pesan yang memiliki kemungkinan semakin rentannya terkena efek buruk dalam proses komunikasi. Belum lagi jika mengarah kepada gugus-gugus kecil dalam komunikasi, yang memiliki kerentanan melebihi topik pembahasan yang lain, seperti komunikasi politik yang sering digunakan untuk menyerang lawan politik atau dengan memanipulasi agama dalam rangka menyukseskan motif politik individu. ${ }^{60}$

59 Haris Sumadiria, Hukum dan Etika Media Massa (Bandung: Rosdakarya offset, 2016), 202.

${ }^{60}$ Roni Tabroni, "Etika Komunikasi Politik dalam Ruang Media Massa”, dalam Jurnal Ilmu Komunikasi, Vol. 10, No. 2, (2012), 113. 
Maka tidak heran jika etika komunikasi yang buruk dapat memberikan dampak negatif yang besar seperti munculnya berita bohong (boax). Hoax merupakan bukti nyata betapa bahayanya komunikasi yang buruk. Hoax yang dapat didefinisikan sebagai "deceive somebody with a hoax" (memperdaya banyak orang dengan berita bohong), memberikan kerugian berupa perpecahan bangsa, provokator kemunduran suatu bangsa, adu domba satu sama lain, bahkan instabilitas publik. ${ }^{61}$

Mengetahui begitu besarnya dampak negatif dari etika komunikasi yang buruk di masyarakat. Maka, terdapat beberapa etika yang dapat dijadikan pedoman berdasarkan hadis ruwaybidah. Pertama, bertindak dan menyampaikan sesuatu sesuai dengan kemampuan yang dimiliki. Karena pada dasarnya, kemampuan adalah pondasi untuk mendapatkan kebenaran. Bagaimana seorang pendakwah bisa menyampaikan kebenaran sedangkan dia sendiri tidak mengetahui apa yang hendak ia sampaikan. Maka tidak berlebihan jika dikatakan bahwa kemampuan adalah basis utama dalam etika komunikasi publik, termasuk dalam proses penyampian informasi secara personal maupun kelompok. Dan pada saatnya, hal tersebut merupakan implementasi nilai-nilai agama yang terkandung dalam hadis Rasulullah tentang ruwaybidah.

Kedua, bersikap jujur, hal ini yang tergambar secara eksplisit dalam hadis ruwaybidah, bahwa adanya tahun-tahun penipuan itu disebabkan karena maraknya pembohongan publik di mana-mana. Poin ini sekaligus meneruskan etika sebelumnya, yakni kemampuan, kalau seseorang sudah mempunyai kemampuan di bidang tertentu, maka ia dituntut untuk bersikap jujur terhadap perbuatan yang dilakukannya.

Ketiga, menyampaikan sebuah informasi bukan hanya berdasarkan nilai informasi tersebut, dalam artian sekedar baik dan benar. Namun, harus menilai kesesuaian dengan konteks yang ada. Kaitannya dengan hal tersebut, sebagaimana peristiwa yang terjadi pada masa sahabat. Pada saat itu, terdapat dua sahabat Rasulullah, 'Umar dengan Abū

${ }^{61}$ Luthfi Maulana, “Kitab Suci dan hoax: Pandangan al-Qur'an dalam Menyikapi Berita Bohong”, dalam Jurnal Wawasan: Jurnal Ilmiah Agama dan Sosial Budaya, Vol. 2, No.2, (2017), 213. 
Hurayrah, yang kala itu Abū Hurayrah ingin menyampaikan sebuah sabda Nabi dengan redaksi sebagaimana berikut ${ }^{62}$ :

$$
\text { من لقيت يشهد أن لاإله لإالله مستيقنا بما قلبه فبشره بالجنة }
$$

"Barangsiapa bertemu denganku (Rasulullah) sedangkan dia meyakini dengan sebenar-benarnya bahwa tiada Tuhan kecuali Allah, maka kabarkanlah kepadanya tentang surga"

Kemudian 'Umar melarang Abū Hurayrah untuk menyampaikan sabda tersebut, hal ini dilakukan dalam rangka menjadikan kaum muslim semakin giat untuk melaksanakan ibadah, karena bisa jadi ketika sabda ini disampaikan kepada umat muslim kala itu, mereka akan merasa malas untuk beribadah, karena dengan meyakini Islam sudah dijamin oleh Nabi dapat masuk surga.

Keempat, memiliki dedikasi dan moral yang baik. hal ini merupakan pelengkap dari dua poin sebelumnya. Karena bagaimanapun moralitas yang dimiliki seseorang ketika menyampaikan informasi menjadi tolak ukur kebenaran yang hakiki. Contoh riil yang bisa dijadikan pemisalan dalam kasus ini, sebagaimana wartawan dan penyiar yang dituntut untuk memiliki keahlian, dedikasi dan moralitas yang sangat tinggi. Karena mereka mempunyai otoritas yang tinggi sebagai sumber informasi di khalayak umum. Karena manipulasi data informasi akan selalu ada, meski seseorang dilengkapi dengan kemampuan namun jika tidak memiliki dedikasi dan moral yang baik maka kebenaran informasi akan kabur atau bahkan dikaburkan. Jadi, pemaknaan ruwaybidah tidak cukup hanya dilekatkan pada orang-orang bodoh yang tidak tahu tentang apa yang dilakukan. Makna ruwaybidah di era sekarang juga menuntut adanya dedikasi yang tinggi bagi setiap orang untuk melakukan apa yang dikerjakan berdasarkan moralitas yang benar.Dengan etika tersebut, setidaknya menjadi tawaran pemaknaan baru (new meanings) terhadap isu komunikasi publik di era modern, berdasarkan sudut pandang hadis ruwaybidah.

\section{Kesimpulan}

Melalui pengkajian tentang hadis ruwaybidah, dapat disimpulkan beberapa poin penting: Pertama, makna ontologis dari ruwaybidah yakni berakar dari kata rabada yang artinya menderum sebagaimana binatang-binatang yang menderum. Kemudian, kata ini juga dapat

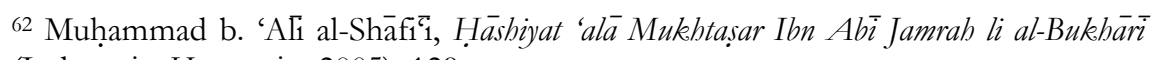
(Indonesia: Haramain, 2005), 129. 
memunculkan makna penggembala yang biasanya menggunakan kata Ra'in. Adapun secara spesifik, bahwa kata ruwaybidah diambil dari kata berbentuk tasghir, rabidah yang berarti orang yang lemah terhadap perkara-perkara yang luhur. Sedangkan dalam konteks hadis tersebut berarti orang bodoh yang turut campur dalam urusan masyarakat luas.

Kedua, sejarah telah mencatat, bahwa secara mikro hadis ini merupakan hadis prediktif yang dilatar-belakangi oleh diri Nabi yang ingin memperingatkan kaum muslim di masa mendatang akan datangnya penipuan-penipuan yang dilakukan oleh ruwaybidah. Sedangkan secara makro, bahwa masyarakat Arab pada abad ke-7 memiliki kepribadian yang baik. Namun, terdapat beberapa peristiwa pembelotan yang dilakukan oleh munafik, dan hal tersebut sangat merugikan umat Islam, sekaligus merusak tatanan ajaran Islam yang dibangun oleh Nabi.

Ketiga, implementasi hadis Ruwaybidah terkait dengan etika berkomunikasi dapat diklasifikasikan sebagai berikut: (1) Bertindak dan menyampaikan sesuatu sesuai dengan kemampuan yang dimiliki; (2) Bersikap jujur, hal ini yang tergambar secara eksplisit dalam hadis ruwaybidah, bahwa adanya tahun-tahun penipuan itu disebabkan karena maraknya pembohongan publik di mana-mana; (3) Menyampaikan sebuah informasi bukan hanya berdasarkan nilai informasi tersebut, dalam artian sekedar baik dan benar. Namun, harus adanya kesesuaian dengan konteks yang ada; (4) Memiliki dedikasi dan moral yang baik.

\section{Daftar Rujukan}

Ahmad, Arifuddin. Paradigma Baru Memahami Hadis Nabi. Jakarta: Insan Cemerlang.

'Asqalāni (al), Shihāb al-Dīn Abī al-Fạ̣l Aḥmad b. 'A $\overline{l i}$ b. Hajar. Tahdhīb al-Tahdhīb. Beirut: Mu'assasat Risālah, 1995.

'Aqiil (ibn), Bahā' al-Din 'Abd Allah. Terjemah Alfiyyah Syarah ibn Aqil. Bandung: Sinar Baru Algensindo, 2015.

Azami, M.M. Hadis Nabi dan Sejarah Kodifikasinya. Terj. Ali Musthofa Ya'qub. Jakarta: Pustaka Firdaus, 2018.

Bukhārì (al), Muhammad b. Ismāīil. Șaḥiḥal-Bukhārì. Beirut: Dār Ibn Kathir, 2002.

Dahlan, Muh. Syawir. "Etika Komunikasi dalam Al-Qur'an dan Hadis". Dakwah Tabligh, Vol. 15, No.1, Juni (2014).

Dihlāwi (al), Wali Allāh. Al-Fawz al-Kabì fī Ușül al-Tafsìr. Kairo: Dār al-Ṣaḥwah, 1987. 


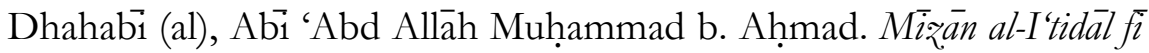
Naqd al-Rijäl. Beirut: Dār al-Kutub al-'Tlmìyah, 1995. . Siyàr A 'làm al-Nubalà.' Beirut: Mu'assasat Risālah.

Hanbal (ibn), Aḥmad. Musnad Aḥmad b. Hanbal. Riyad: Bayt al-Afkār, 1998.

Heri Budianto dan Farid Hamdi. Ilmu Komunikasi: Sekarang dan Tantangan Masa Depan. Jakarta: Kencana, 2013.

Hishām (ibn), 'Abd al-Mālik. Al-Sīrah al-Nabawīyah. Beirut: Dār Ibn Hazm, 2009.

Khațīb (al), Muhammad 'Ajjaj. Ușul al-Hadìth: Ulumuh wa Muștalahuh. Damaskus: Dār al-Fikr, 2011.

Hitti, Philip K. History of the Arabs. Terj. Cecep \& Dedi. Jakarta: Zaman, 2018.

Ismail, Faisal. Sejarah \& Kebudayaan Islam: Periode Klasik (Abad VIIXIII M). Yogyakarta: IRCiSoD, 2017.

Jabīrī (al), 'Abīd. Bunyat al-'Aql al-'Arabì. Beirut: Markaz Dirāsat alWahdah al-'Arabiyah, 1989.

Takwin al-'Aql al-'Arabī. Beirut: Markaz Dirāsat al-Waḥdah al-'Arabiyah, 1989.

Kathïr (Ibn), Ismāīil b. 'Umar. Al-Bidāyah wa al-Nihāyah. Riyad: Dār alWațan, 2002.

Kurnia, Novi. "Perkembangan Teknologi Komunikasi dan Media Baru: Implikasi terhadap Teori Komunikasi". Jurnal Mediator. Vol. 6, No. 2 (2005).

Manzūur (Ibn), Abī Faḍl Muhammad. Lisān al-'Arab. Kairo: Dār alMa árif, $1119 \mathrm{H}$.

Maulana, Luthfi. "Kitab Suci dan hoax: Pandangan al-Qur'an dalam

Menyikapi Berita Bohong". Wawasan: Jurnal Imiah Agama dan Sosial Budaya, Vol. 2, No.2, (2017).

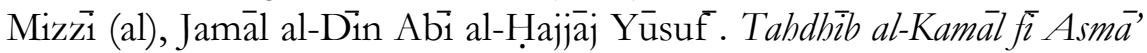
al-Rijāl. Beirut: Mu’assasat Risālah, 1983.

Mughlațài (ibn), 'Alā' al-Dīn. Sharh Sunan Ibn Mäjah. Riyad: Maktabat Nizar Muștafá al-Bāz, 1999.

Muna, Moh. Nailul. "Ragam Pemaknaan Jihad Dalam Kitab Fath alBari dan Irsyad al-Sari". Mutawatir: Jurnal Keilmuwan Tafsir Hadis, Vol. 7, No. 2 (2017).

Munawwir, A.W. Kamus Al-Munawwir Arab-Indonesia Terlengkap. Surabaya: Pustaka Progressif, 1997. 
Mustaqim, Abdul. Ilmu Ma'anil Hadits: Paradigma Interkoneksi. Yogyakarta: Idea Press, 2016.

Nurudin, Muhammad. "Aktualisasi Pemahaman Hadis Hukum dalam Kehidupan Global”. Riwayah, Vol. 1, No. 1, Maret (2015).

Qadafy, Mu'ammar Zayn. Buku Pintar Sababun Nuzul Dari Mikro Hingga Makro: Sebuah Kajian Epistemologis. Yogyakarta: In AzNa Books, 2015.

Qazwayni (al), 'Abd Allāh Muhammad b. Yazid b. Mājah. Sunan Ibn Mäjah. Riyad: Dār al-Khaḍrā', 2015.

Sindi (al), Abū Husayn. Sunan Ibn Mäjah bi Sharb al-Sindī wa Mișbāḥ alZujajah. Beirut: Dār al-Ma'rifah.

Sumadiria, Haris. Hukum dan Etika Media Massa. Bandung: Rosdakarya Offset, 2016.

Şuyūṭi (al), Jalāl al-Dīn. Shurụ̣̄ Sunan Ibn Mājah. Beirut: Bayt al-Afkār, 2007.

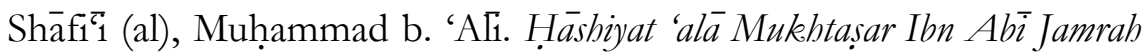
li al-Bukhari. Indonesia: Haramain, 2005.

Tabarānì (al), Aḥmad. Mújam al-Kabir. Kairo: Maktabat Ibn Taymiyah. Tabroni, Roni. "Etika Komunikasi Politik dalam Ruang Media Massa". Jurnal Ilmu Komunikasi, Vol. 10, No. 2, (2012).

Watie, Errika Dwi Setya. "Communication and Social Media". Jurnal The Messenger. Vol. 3, No. 1 (2011).

Zamroni, Mohammad. "Perkembangan Teknologi Komunikasi dan Dampaknya terhadap Kehidupan". Jurnal Dakwah, Vol. 10, No. 2 (2009). 